\author{
Stanisław Liszewski \\ Katedra Geografii Miast i Turyzmu \\ Uniwersytetu Łódzkiego \\ ul. Kopcińskiego 31 \\ 90-142 Łódź \\ tel./fax 42 635-45-50, 635-45-52
}

\section{METODY STYMULOWANIA ROZWOJU TURYSTYKI W UJĘCIU PRZESTRZENNYM,
2002, PRACA ZBIOROWA UJĘCIU PRZESTRZENNYI
2002, PRACA ZBIOROWA POD RED. GRZEGORZA GOEEMBSKIEGO, POZNAŃ, 316 ss.}

\section{METODY STYMULOWANIA ROZWOJU TURYSTYKI W UJECIU PRZESTRZENNYM [METHODS FOR STIMULATING TOURISM DEVELOP- MENT - A SPATIAL APPROACH ], 2002, A COLLECTIVE WORK SUPERVISED BY GRZEGORZ GOŁEMBSKI, POZNAŃ, 316 pp.}

Praca zatytułowana Metody stymulowania rozwoju turystyki w ujęciu przestrzennym jest dziełem zbiorowym przygotowanym przez pracowników Akademii Ekonomicznej w Poznaniu. W spisie treści zaznaczono autorów poszczególnych rozdziałów. Została ona podzielona na trzy obszerne rozdziały (bardziej części), które tworzą zwartą całość prezentując obszerną gamę metod pozwalających identyfikować, a następnie sterować rozwojem turystyki na określonym obszarze, nazywanym w pracy, dość umownie, regionem. We wstępie autorzy wyrażają nadzieję, iż przedstawione przez nich metody mają charakter uniwersalny, co pozwoli zastosować je na szeroką skalę w odniesieniu do regionów wiejskich.

Pierwszy rozdział pracy, pt. „Wyodrębnienie przedsięwzięć turystycznych o znaczeniu ponadregionalnym", poświęcony został delimitacji obszarów, nazwanych przez autorów terenami „o szczególnej atrakcyjności turystycznej”, oraz prezentacji metod badania infrastruktury turystycznej i atrakcji turystycznych w skali gminy.

Składa się on z trzech części. W pierwszej autorzy definiują i omawiają inwestycje proturystyczne, kryteria ich lokalizacji oraz stosunek do nich zarówno władz lokalnych, jak i samych inwestorów.

Druga część tego rozdziału poświęcona została prezentacji metod, które mogą być pomocne przy delimitacji obszarów o szczególnej atrak-
Methods for stimulating tourism development - a spatial approach is a collective work prepared by a team from the Academy of Economics in Poznan. The Contents section includes the names of the authors of individual chapters. The book is divided into three large sections presenting a wide range of methods used for identifying and then controlling tourism development in a given area, called a region. In the introduction the authors express their hope that the methods they present are universal, and can be used on a large scale in reference to rural regions.

The first chapter entitled 'Tourist undertakings of national importance' is devoted to the delimitation of areas called by the authors "areas of particular tourist attractiveness", as well as to the presentation of methods used for studying tourist infrastructure and tourist attractions within a single gmina. The chapter consists of three sections. In the first the authors define and discuss tourist investments, their location criteria, as well as the attitude assumed by both the local authorities and the investors themselves towards them.

The second section is devoted to methods which may be helpful in the 
cyjności turystycznej. Jako teren swoich badań autorzy wybrali region przyrodniczy Pojezierza Pomorskiego, a bardziej szczegółowo, obszary zamknięte granicami dwóch województw: zachodniopomorskiego i pomorskiego.

Aby ocenić atrakcyjność obszarów, posługując się wskaźnikami syntetycznymi określono: atrakcyjność turystyczna, atrakcyjność inwestycyjną i atrakcyjność ogólną dla wszystkich gmin znajdujących się w granicach obu województw (łącznie 237). Porządkując cały zbiór, do dalszych badań wybrano łącznie 36 gmin $(20 \mathrm{z}$ województwa zachodniopomorskiego i $16 \mathrm{z}$ pomorskiego), których wskaźniki atrakcyjności turystycznej przekraczały wartość górnej granicy obszaru zmienności. $\mathrm{Z}$ dalszych analiz à priori wyłączono gminy nadmorskie, które pod względem wskaźnika atrakcyjności ogólnej plasowały się na pierwszych pozycjach. Odrzucenie tych gmin wynika z przyjętego wcześniej założenia tego studium, które ma na celu wypracowanie metod pozwalających na stymulowanie rozwoju turystyki na obszarach wiejskich atrakcyjnych turystycznie, ale jeszcze słabo zainwestowanych. Założeniu temu nie odpowiadały gminy nadmorskie.

W konsekwencji zastosowanej procedury, grupując sąsiednie gminy, wydzielono sześć obszarów w województwie zachodniopomorskim (szczeciński, nadgraniczny, drawski, myśliborski, południowy i północny) oraz pięć w województwie pomorskim (wejherowski, Szwajcaria Kaszubska, chojnicki, zachodniobytowski i wschodniobytowski). W trzeciej części tego rozdziału zaprezentowano metody badania infrastruktury turystycznej i atrakcji turystycznych $w$ gminach. Badania empiryczne przeprowadzono $w$ trzech obszarach nazwanych regionami: drawskim, chojnickim i na terenie Szwajcarii Kaszubskiej. Łącznie szczegółowe studia terenowe (m.in. badania ankietowe) przeprowadzono w 15 gminach. Analiza poszczególnych regionów wykonana została wg ujednoliconego schematu obejmującego ogólną charakterystykę regionu, możliwości rozwoju produktów turystycznych, ograniczenia rozwoju produktów turystycznych i propozycje rozwoju infrastruktury turystycznej. Rozdział pierwszy bardzo bogaty w treści metodyczne, moim zdaniem, ma kluczowe znaczenie teoretyczne dla całego dzieła. Jest on skonstruowany bardzo logicznie, a wybór obszarów badań poprzedzony jest rzetelną analizą znacznie większego terytorium (dwa województwa). Po zapoznaniu delimitation of particularly attractive areas. The authors selected the Pomorski Lake District (to be more precise: an area delimited by the borders of the Zachodniopomorski and Pomorski województwos) to be their research area.

In order to evaluate the attractiveness of the area, the authors used standardized indicators and measured the tourist, investment and general attractiveness of all the gminas within the two województwos (237 in total). After ordering the whole set, 36 gminas were chosen for further study (20 from the Zachodniopomorski województwo and 16 from the Pomorski województwo) whose tourist attractiveness indicators were higher than the upper limit of variation within the region. Coastal gminas with the highest general attractiveness indicators were a priori excluded from further analysis. This rejection naturally results from their aim of establishing tourism development stimulation methods in touristically attractive, but still underdeveloped, rural areas. The coastal areas did not fit into this category.

By grouping adjacent gminas, six regions were delimited in the Zachodniopomorski województwo (Szczeciński, Drawski, Myśliborski, Border, Southern and Northern) and five in the Pomorski Województwo (Wejherowski, Swiss Kaszuby, Chojnicki, Bytowski-west and Bytowski-east).

The third section presents methods of evaluating tourist attractiveness and tourist attractions in the gminas. Empirical study was conducted in the Drawski, Chojnicki and Swiss Kaszuby regions and a detailed field study (e.g. a survey) was carried out in 15 gminas. The analysis of individual regions was based on a model including a general description of the region, prospects for and limitations in tourist product development, as well as suggestions for tourist infrastructure development. In my opinion, the methodological content of the first chapter is very rich and of key theoretical importance for the whole book. It is logically constructed and the choice of the study areas was preceded by a thorough analysis of a considerably larger territory (two województwos). The 
się z treścią tego rozdziału nasuwa się kilka uwag do dyskusji.

Pierwsza dotyczy formalnego, administracyjnego podejścia do badań regionalnych. Jest sprawą zrozumiałą, iż prowadząc badania przestrzenne musimy poszukiwać odpowiedniej jednostki terytorialnej jako podstawowego pola badawczego. Przyjęcie gminy jako podstawowej jednostki przestrzennej jest poprawne, natomiast grupowanie gmin $w$ granicach jednego województwa i nazywanie tego regionem może budzić zastrzeżenia. Walory turystyczne, zwłaszcza przyrodnicze, w niewielkim stopniu są uwzględniane w podziałach administracyjnych i dlatego np. pewnym zubożeniem obszaru nazywanego w pracy „regionem chojnickim” jest brak w nim gminy Tuchola, która mimo pokrewieństwa przyrodniczego i nie tylko, leży już $w$ innym województwie. Jest to oczywiście przykład jednostkowy, ale problem bardziej ogólny, dotyczy definicji i delimitacji regionu turystycznego, co - moim zdaniem - w badaniach przestrzennych rozwoju turystyki jest sprawą pierwszoplanową.

Druga uwaga jest pewnym komentarzem do koncepcji zrównoważonego rozwoju. Zgadzam się z autorami, którzy podejmują problem obszarów prawnie chronionych w kontekście rozwoju turystyki. To prawda, że utworzenie parku narodowego czy krajobrazowego jest automatycznie promocją turystyczną tego terenu, co przynosi często efekt odwrotny do zamierzonego. Myślę jednak, iż planując rozwój inwestycji turystycznych na obszarach wiejskich, zwłaszcza atrakcyjnych przyrodniczo, trzeba koniecznie do zaprezentowanego $\mathrm{w}$ pracy zestawu metod dołączyć metody pozwalające ocenić chłonność turystyczną obszaru, bez tego nie powinniśmy rozpoczynać żadnej działalności inwestycyjnej.

Wydaje się również, że nie bez znaczenia przy konstruowaniu programu turystyki na określonym terenie są studia demograficzno-społeczne w odniesieniu do miejscowej ludności i to zarówno w zakresie wieku czy bezrobocia, co w pracy jest podnoszone, jak również zasiedziałości - czyli tzw. korzeni tej ludności. Zupełnie inaczej reaguja na możliwości rozwoju turystyki na swoich terenach społeczności lokalne o starych i głębokich korzeniach i tradycji turystycznej (np. kaszubi, górale), a inaczej ludność, która w pierwszym czy drugim pokoleniu zamieszkuje te ziemie.

Ostatnią sprawą dyskusyjną, którą chcę tu tylko zasygnalizować, jest metoda określania atrakcyj- first chapter does bring up a few issues for discussion however.

The first regards the formal, administrative approach to regional studies. It is obvious that when conducting spatial research we must find an appropriate territorial unit as the basic research field. Selecting a gmina seems appropriate, while grouping gminas within a województwo and calling them a region, may cause reservations. Tourist assets, especially natural ones, are not widely considered in administrative divisions, so for instance the fact that the Chojnicki region does not include the gmina of Tuchola (similar environmentally but belonging to another województwo) works against it. It is of course an isolated example, but there is a more general problem of the definition and delimitation of a tourist region which, in my view, is of the utmost importance in the spatial study of tourism development.

The other observation is a comment on the balanced development concept. I agree with the authors in their discussion of the problem of areas protected by law in the context of tourism development. It is true that creating a national or landscape park is an automatic tourist promotion of the area which often brings counter effects. I believe, however, that planning tourist investment in rural areas, especially those environmentally attractive, one should employ methods which allow us to evaluate the capacity of the area for absorbing tourists. Investment activity should not be initiated without them.

It also seems that when constructing a development programme for tourism in a given area we should not neglect a demographic and social study of the local community, considering age structure and unemployment rate (which is mentioned in the book), as well as period of residence. Local communities, long and deeply rooted in an area with rich tourist traditions (e.g. Kaszubians and Highlanders) react to the prospects of tourism development quite differently from a community that has lived in an area for just one or two generations.

The last controversial issue which I want to point to is the method of 
ności turystycznej, zwłaszcza w odniesieniu do walorów turystycznych. Ponieważ każda z prezentowanych $\mathrm{w}$ literaturze metod, starających się określić ilościowo walory turystyczne jest $\mathrm{w}$ jakimś stopniu ułomna, proponuję przy wprowadzaniu nowych sposobów czy metod odnieść się do poprzednich, wyjaśniając konieczność wprowadzenia własnej. Literatura na ten temat, zwłaszcza geograficzna, ale również botaniczna, jest bardzo bogata.

Drugi rozdział pracy zatytułowany „Metody określenia: rozmiaru i opłacalności inwestycji turystycznych w regionie" ma charakter warsztatowy $\mathrm{i} w$ sposób bardzo uporządkowany pozwala czytelnikowi prześledzić cały cykl metod i analiz prowadzących od określenia lokalizacji szczegółowej inwestycji turystycznej w regionie przez analizę marketingową sfery podaży, badanie ruchu turystycznego jako miary popytu turystycznego, metodę opracowania programu użytkowo-funkcjonalnego inwestycji, wycenę nakładów, metodę szacowania przychodów i kosztów do analizy ekonomiczno-finansowej przedsięwzięcia inwestycyjnego.

Analiza opłacalności inwestycji turystycznej pokazana tu została na konkretnie wybranych przykładach. Są to trzy proponowane obiekty nad jeziorami: wodne centrum sportowo-rekreacyjne (Gwda Wielka w gminie Szczecinek), ośrodek rekreacyjno-sportowy (Borne Sulinowo) oraz stanica wodna (Liszkowo), a także dwie propozycje obiektów hotelarskich (motel i kompleks hotelarski).

Szczegółowy program funkcjonalno-użytkowy przykładowo przedstawiono dla centrum sportowo-rekreacyjnego w Gwdzie Wielkiej i motelu w Krągach. Ta część pracy może służyć jako przewodnik dla podejmujących studia nad lokalizacją inwestycji turystycznych na obszarach wiejskich.

Trzeci i ostatni rozdział dotyczy „Miejsca i roli samorządu terytorialnego w fazie budowy i realizacji projektów inwestycyjnych". Ta część pracy poświęcona została zadaniom, jakie stoją przed władzami lokalnymi, które pragną aktywizować swoje gminy przez inwestycje turystyczne. Szczególnie cenne, moim zdaniem, są te fragmenty tego rozdziału, które dotyczą „metody badania sytuacji finansowej gmin turystycznych”, „możliwości wykorzystania środków pomocowych" czy „tworzenia strategii rozwoju lokalnego".

Także i w tym rozdziale autorzy wykorzystali badania ankietowe przeprowadzone wśród przed- evaluating tourist attractiveness, particularly in reference to tourist assets. Like every method presented in the literature which attempts to describe tourist assets quantitatively it is to some extent insufficient, and I suggest reference to previously described methods when introducing a new one. There are vast resources to use both in geographical and botanical literature.

The second chapter, entitled 'Methods of establishing the range and cost-effectiveness of tourist investments in the region', is of a workshop type and allows the reader to follow the whole cycle of methods and analyses for establishing the location of tourist investment in the region. The cycle includes a marketing supply analysis, a study of tourist activity as a measure of tourist demand, a method of programming an investment, cost evaluation, as well as a method of evaluating the costs and profit for the purposes of an economic and financial analysis of the investment.

The analysis of the cost-effectiveness of a tourist investment is presented for selected examples of three complexes located by lakes: a water sports and recreation centre in Gwda Wielka (Szczecinek gmina), a sports and recreation centre in Borne Sulinowo and a riverside hostel in Liszkowo, as well as two hotel establishments (a motel and a hotel complex).

The chapter presents a detailed functional and exploitation programme for the centre in Gwda Wielka and for the motel in Kragi. This section of the book may serve as a guide for those beginning a study of tourist investment location in rural areas.

The third and last chapter is entitled 'The place and role of a territorial selfgovernment in the phase of investment realization' and devoted to tasks for local authorities which want to activate their gminas through tourist investment. In my view, the particularly valuable sections are those referring to the "methods for analysing the financial situation of tourist gminas", "opportunities for exploiting financial means of support" and "creating local development strategies". 
stawicieli samorządów lokalnych, turystów oraz podmiotów świadczących usługi turystyczne. Ostatnia część tego rozdziału poświęcona została zasadom zarządzania zintegrowanym produktem turystycznym. Szczególnie interesujący jest tu wywód poświęcony przywództwu w zarządzaniu jakością na obszarach turystycznych, co w konsekwencji może zdecydować o szansie i możliwości rozwoju turystyki na konkretnym obszarze.

Pracę zamyka krótkie „Zakończenie”, w którym ponownie wymieniono metody stymulowania rozwoju turystyki w ujęciu przestrzennym. W aneksie załączono zestawienia statystyczne oraz wzór ankiety dla turystów przeprowadzonej na obszarze Pojezierza Drawskiego. Na końcu pracy zamieszczono wykaz podstawowej literatury.

Recenzowana praca jest pozycją wartościową tak ze względu na podjętą tematykę badawczą, jak i zakres merytoryczny.

Po raz pierwszy w polskiej literaturze dotyczącej turystyki ukazało się dzieło, w którym autorzy kompleksowo omówili i zaprezentowali zbiór różnorodnych metod, za pomoca których można określić możliwości rozwoju turystyki na wybranych przykładach. Wyjątkowość tej pracy polega jednak nie tylko na zaprezentowaniu metod, ale głównie na ich przetestowaniu na wyznaczonych obszarach Pojezierza Pomorskiego. W ten sposób otrzymaliśmy opracowanie bogate $w$ treści teoretyczno-metodyczne, ale przede wszystkim będące swoistym przewodnikiem naukowym dla tych, którzy zajmują się rozwojem turystyki $w$ ujęciu przestrzennym, czyli dla szerokiego spektrum odbiorców. Możliwość praktycznego zastosowania zaprezentowanych metod badawczych jest znaczącym walorem tej książki.

Jako geograf, ze szczególnym zadowoleniem witam pracę dotycząca problematyki przestrzennej turystyki przygotowaną przez zespół ekonomistów. Myślę, że jest to dobry przykład potwierdzający, że turystyka jest wiedzą interdyscyplinarną, a uprawiający ją badacze reprezentując różne dziedziny i dyscypliny naukowe spotykają się w przestrzeni geograficznej, która jest przecież główną płaszczyzną turystycznej działalności człowieka.
In this chapter the authors made use of a survey conducted among the representatives of local authorities, tourists or those running tourist services. The last section is devoted to the principles of managing an integrated tourist product. A particularly interesting idea here is that of leadership in quality management in tourist areas, which in consequence can determine the development of tourism in a given area.

The book closes with brief final remarks where again methods of stimulating the development of tourism in a spatial perspective are mentioned. The appendix includes the statistics and the survey questionnaire for tourists used in Drawskie Lake District. At the end of the book we find a basic bibliography.

The book is a valuable publication for the kind and range of the research issues it discusses. It is the first book in the literature of Polish tourism where the authors so widely discuss and present the variety of methods which can be used for evaluating the possibilities of tourism development, using selected examples. The exceptional character of this work, however, consists not only in the presentation of the methods, but more in their testing in chosen areas of the Pomorski Lake District. In this way we have obtained a book rich in theoretical and methodological considerations which is above all a particular kind of research guide for those interested in tourism development in a spatial perspective which means a wide range of readers. The possibility of the practical application of the methods presented is a significant asset.

As a geographer I am pleased to welcome a book about the spatial problems of tourism prepared by a team of specialists. I think that it is a good example confirming tourism as an interdisciplinary theme, and proving that researchers representing different academic domains can meet in geographical space, the main field of human tourist activity. 